\title{
Knowledge, attitude, and practice (KAP) about Hepatitis B Infection among nursing students in Sabya College, Saudi Arabia
}

Hind Abdallah Modawi ${ }^{1}$, Manal Bilal Mohamed ${ }^{2,3}$, Iman Khalifa Abdel Gadir ${ }^{2,4}$, Norah Hassan Ahmed ${ }^{5}$, Khadijah Mohammed Ismail Zaeri ${ }^{5}$

${ }^{1}$ M.Sc., Lecturer, Department of Nursing, Sabya University College, Jazan University, Jazan, Kingdom of Saudi Arabia

${ }^{2}$ Ph.D., Assistant Professor, Department of Nursing, Sabya University College, Jazan University, Jazan, Kingdom of Saudi Arabia

${ }^{3}$ Ph.D., Assistant Professor, Department of Nursing, Omdurman Islamic University, Khartoum, Sudan

${ }^{4}$ Faculty of Science and Technology, Shendi University, Sudan

${ }^{5}$ Department of Nursing, Sabya University College, Jazan University, Jazan, Kingdom of Saudi Arabia

\section{Type of article: Original}

\begin{abstract}
Background: Hepatitis B is a serious global public health problem. Nursing students' risk of exposure to HBV during their training period is a chief concern. Therefore, they should have adequate knowledge and practice towards HBV.

Objective: To determine the knowledge, attitude, and practice (KAP), regarding Hepatitis B Virus Infection among nursing students in Sabya Campus of Jazan University, Saudi Arabia.

Methods: This cross-sectional study was conducted using a validated questionnaire to assess the KAP of nursing students regarding hepatitis B infection. The study was conducted from May to June 2018, Data of 60 students from level 4 to level 8were analyzed using IBMC SPSS $\odot$ Statistics version 20. Descriptive statistics including frequencies and proportions were performed. Chi-squared test was used to determine the association of independent variables (age, educational level, marital status) with the outcome variable of interest (knowledge, attitude, and practice, related to hepatitis B). A p-value $<0.05$ was considered statistically significant.

Results: Sixty students participated in the study, $51.7 \%$ of them had good knowledge. Only $16.7 \%$ had good attitudes while most of them $(48.3 \%)$ had poor attitudes towards people infected with the hepatitis B virus. Seventy-six point seven percent had good practices. A significant difference was found between the marital status and the attitude towards HBV infection ( $\mathrm{p}=0.024)$.

Conclusion: The study emphasizes the necessity of continued education about HBV to improve knowledge and attitude toward HBV infection.

Keywords: Hepatitis B, Nursing students, Sabya, Saudi Arabia
\end{abstract}

\section{Abbreviation / acronyms:}

HBsAg: Hepatitis B Surface Antigen; HBV: Hepatitis B Virus; HCV: Hepatitis C Virus; KAP: Knowledge, Attitude, and Practice; WHO: World Health Organization

\section{Introduction}

Hepatitis B is a serious infectious disease of the liver caused by the virus Hepatitis B (HBV), a major global health problem that can cause chronic and often fatal liver diseases, such as liver cirrhosis and cancer (1). It is regarded as

\section{Corresponding author:}

Hind Abdallah Modawi. Department of Nursing, Sabya University College, Jazan University, Jazan, Kingdom of Saudi Arabia. Tel: +966538290250, E-mail: hindmodawi@gmail.com

Received: February 13, 2020, Accepted: March 02, 2020, Published: September 2020

iThenticate screening: February 17, 2020, English editing: August 18, 2020, Quality control: June 04, 2020

This article has been reviewed / commented by three experts

Ethics approval: research ethics committee of Jazan University (HAPO-10-Z-001), ref: REC39/9-S049

(C) 2020 The Authors. This is an open access article under the terms of the Creative Commons Attribution-NonCommercialNoDerivs License, which permits use and distribution in any medium, provided the original work is properly cited, the use is non-commercial and no modifications or adaptations are made. 
the tenth leading cause of death all over the world, it doesn't have any seasonal spreading $(2,3)$. The worldwide prevalence of hepatitis B infection has decreased after the introduction of the hepatitis B vaccine and other preventive measures. However, chronic infection remains a challenging global health problem, as about 2 billion people are estimated to be infected and more than 350 million people chronically infected and at risk of hepatic decompensation, cirrhosis, and hepatocellular carcinoma (4).

Infection with HBV may be subclinical or asymptomatic, but it may cause acute self-limited hepatitis, or fulminant hepatitis requiring liver transplantation. The infected persons may also develop chronic HBV infection, which can lead to cirrhosis or hepatocellular carcinoma. The likelihood of progressing to chronic HBV infection is dependent on their age at the time of infection (5). The risk of progression to chronic hepatitis is much higher in vertical transmission (around 90\% of infected infants progress to chronic hepatitis B) than from horizontal transmission where the rate of chronicity is $30-50 \%$ when infected before 6 years of age and $<5 \%$ when infected in adulthood $(6$, 7). The incubation period of HBV infection averages 60-90 days, with a range of 45-160 days (8). The overall prevalence of HBV in Saudi Arabia of $1.7 \%$ and $8.7 \%$ was found among health college students and health care workers, respectively (9). The prevalence in Jazan region was found to be $8.3 \%$ in 2015 which was high relative to the KSA national level. It was higher in people aged more than 60 years, family history and dental procedures increase the risk of infection (10). A study conducted in 2018 showed a higher prevalence rate $(1.9 \%)$ in males than in females (1.43\%) (11). However, the prevalence decreased from 5.6\% in 2004 to $2.3 \%$ in 2009 most probably due to the application of the children's HB immunization programs (12).

Transmission of HBV occurs through percutaneous or mucosal exposure to infected blood or other body fluid. It can also occur by many other forms of human contact: perinatal/mother-to-child; household (nonsexual); sexual; needlesharing; and occupational/health-care-related. Blood and serum have the highest concentrations of infectious HBV, other serum-derived body fluids, such as semen and saliva, are also infectious; with saliva containing the lowest concentrations of HBV (13). The major reservoir of the virus is the person with chronic HBV infection, however, any person testing positive for Hepatitis B surface antigen $(\mathrm{HBsAg})$ is potentially infectious to both household and sexual contacts. The risk of transmission indirectly via contaminated surfaces and other objects is present because HBV can remain stable and infectious on environmental surfaces for at least 7 days (14). Health care personnel are at increased risk of contracting blood borne pathogens due to their occupational exposure to blood and body fluids. The World Health Organization (WHO) estimated that, of the 35 million HCWs worldwide, 3 million experience percutaneous exposures to blood pathogens each year, of these 2 million are exposed to the hepatitis B virus (15). Because of their training in the hospitals, nursing students are exposed to the risk of hepatitis B infection, as they may come in contact with hepatitis B infected patients or carriers. Therefore, a culture of safety precaution, proper preventive methods, and the infection control practice should be implemented among those students. The students should have adequate knowledge about transmission of hepatitis B virus, incubation period, high-risk groups, signs, and symptoms of $\mathrm{HBV}$, plus adequate training on how to protect themselves and their patients, as well as the foundation of safe working conditions.

Some studies were done in Saudi Arabia which assessed the knowledge, attitude, and practices about Hepatitis B infection among medical or dental students $(16,17)$; but data about nursing students are lacking. This study aimed to determine the knowledge, attitude, and practices of nursing students regarding hepatitis B infection in Sabaya Campus of Jazan University, Saudi Arabia.

\section{Material and Methods}

\subsection{Research design and instrument}

This cross-sectional study was carried out on all nursing students from level 4 to level 8 studying at Sabya University College, Jazan University, Kingdom of Saudi Arabia from May 01 to June 01, 2018, using a pre-designed questionnaire which included questions designed to fulfil the study objectives (18). The questionnaire consisted of four main parts (Table 1):

1) Part 1: Questions covering socio-demographic characteristics of students including age, marital status, and academic year.

2) Part 2: Questions to discuss knowledge about hepatitis B infection, including the cause of disease, symptoms, ways of transmission, complications, and prevention.

3) Part 3: Questions to discuss the attitude of the students towards hepatitis B infection: living with an infected person, marrying an infected person, breastfeeding of an infected mother to her baby, helping an infected patient in case of emergency, and feeling toward a patient with the disease. 
http://www.ephysician.ir

4) Part 4: Questions to discuss the practice of the students to protect their patients and themselves from hepatitis B infection: ways of safe disposal of medical wastes.

Table 1. The questionnaire used as the measurement tool in the KAP (Knowledge, Attitudes, Practice) study

\begin{tabular}{|c|c|c|}
\hline Knowledge questionnaire & Attitude questionnaire & Practice questionnaire \\
\hline $\begin{array}{l}\text { Did you hear about hepatitis B } \\
\text { virus infection }\end{array}$ & $\begin{array}{l}\text { If your husband is infected } \\
\text { can you live with him }\end{array}$ & Not to put hands in medical waste containers \\
\hline $\begin{array}{l}\text { The cause of the disease is a } \\
\text { virus }\end{array}$ & $\begin{array}{l}\text { You will travel to a place } \\
\text { where there is the disease }\end{array}$ & $\begin{array}{l}\text { Not to throw medical wastes in the opened piles of } \\
\text { garbage in the streets }\end{array}$ \\
\hline $\begin{array}{l}\text { There is a vaccine for hepatitis } \\
\text { B virus }\end{array}$ & $\begin{array}{l}\text { You will live in the same } \\
\text { house with an infected } \\
\text { person }\end{array}$ & $\begin{array}{l}\text { Colored plastic bags should be used to distinguish } \\
\text { between medical and general waste }\end{array}$ \\
\hline $\begin{array}{l}\text { Health care workers are at } \\
\text { increased risk of infection }\end{array}$ & $\begin{array}{l}\text { You will work in the same } \\
\text { place with an infected } \\
\text { person }\end{array}$ & $\begin{array}{l}\text { The vessels used for medical waste should be } \\
\text { cleaned with disinfectant at least once a day. } \\
\text { Cleaners should wear thick gloves and eye masks } \\
\text { when cleaning them }\end{array}$ \\
\hline $\begin{array}{l}\text { Multiple sex partners are at } \\
\text { high risk of infection }\end{array}$ & $\begin{array}{l}\text { You will marry an infected } \\
\text { person }\end{array}$ & $\begin{array}{l}\text { Red bags are used for infectious and disease-borne } \\
\text { waste, which must be disposed of by burning. }\end{array}$ \\
\hline $\begin{array}{l}\text { Newborn babies are at risk of } \\
\text { infection }\end{array}$ & $\begin{array}{l}\text { If an infected person had an } \\
\text { accident or emergency you } \\
\text { will help him }\end{array}$ & $\begin{array}{l}\text { Yellow bags, used for radioactive waste and to be } \\
\text { sent to bodies operating in atomic energy to deal } \\
\text { with }\end{array}$ \\
\hline $\begin{array}{l}\text { Hepatitis B virus is transmitted } \\
\text { through body fluids }\end{array}$ & $\begin{array}{l}\text { The infected mother can } \\
\text { breastfeed her baby }\end{array}$ & $\begin{array}{l}\text { Black bags are used for general waste, which is } \\
\text { disposed of in normal ways and transported by cars } \\
\text { belonging to local councils }\end{array}$ \\
\hline $\begin{array}{l}\text { Hepatitis B virus is transmitted } \\
\text { from mother to her baby }\end{array}$ & $\begin{array}{l}\text { What is your feeling } \\
\text { toward the patient with } \\
\text { hepatitis }\end{array}$ & $\begin{array}{l}\text { Not to dump medical waste in open vehicles, } \\
\text { which increases the risk of injury to workers, } \\
\text { patients, and visitors }\end{array}$ \\
\hline $\begin{array}{l}\text { Hepatitis B virus is transmitted } \\
\text { through shaking hands }\end{array}$ & & Waste disposal containers should be covered \\
\hline \multicolumn{3}{|l|}{$\begin{array}{l}\text { Hepatitis B virus is transmitted } \\
\text { through sharing sharp } \\
\text { equipment (e.g. shaving tools) }\end{array}$} \\
\hline \multicolumn{3}{|l|}{$\begin{array}{l}\text { The appearance of symptoms } \\
\text { occurs immediately after } \\
\text { infection }\end{array}$} \\
\hline \multicolumn{3}{|l|}{$\begin{array}{l}\text { Jaundice and dark urine are } \\
\text { some of the symptoms of the } \\
\text { disease }\end{array}$} \\
\hline \multicolumn{3}{|l|}{$\begin{array}{l}\text { Diagnosis is done through } \\
\text { testing urine and blood }\end{array}$} \\
\hline \multicolumn{3}{|l|}{$\begin{array}{l}\text { Liver cirrhosis and hepatic } \\
\text { cancer are complications of the } \\
\text { disease }\end{array}$} \\
\hline $\begin{array}{l}\text { Using gloves and sterile } \\
\text { equipment are ways of } \\
\text { prevention }\end{array}$ & & \\
\hline
\end{tabular}

\subsection{Statistical analysis}

Data were analyzed using IBMC SPSS $\odot$ Statistics version 20 (IBM@ Corp., Armonk, NY, USA). In addition to descriptive statistics, a Chi-squared test was used to determine the association of independent variables (age, educational level, marital status) with the variables of interest (knowledge, attitude, and practice related to hepatitis B) with a p-value $<0.05$ was considered statistically significant. 


\subsection{Ethics of research}

This research was approved by the scientific research ethics committee of Jazan University (HAPO-10-Z-001), reference number: REC39/9-S049.

\section{Results}

\subsection{Sociodemographic characteristics}

Sixty students participated in the study (included all the students studying at levels 4-8). All of them were females (Sabya University College is a campus for female students). Regarding the socio-demographic characteristics of the participants, most of them (81.7\%)were $21-22$ years old, the majority were single $(80 \%)$, and $38.4 \%$ of them were in the higher educational levels (level: 7-8).

\subsection{Knowledge}

Regarding the students' knowledge about hepatitis B infection (Table 2), most (76.7\%) of the students heard about the disease, $75 \%$ stated that it is caused by a virus but $20 \%$ didn't know whether it is a viral infection or not. Among the respondents, $68.3 \%$ knew that there is a vaccine while $10 \%$ replied that there is no vaccine for the hepatitis $\mathrm{B}$ virus. Only $48.3 \%$ realized that health care workers are at high risk while $35 \%$ did not know if the health workers are at high risk. More than half, $55 \%$ of the respondents realized that multiple sex partners and newborn babies are at high risk of infection. Regarding ways of transmission $43.3 \%$ stated that the virus can be transmitted through body fluids, $46.7 \%$ realized that the virus can be transmitted from mother to her baby while $28.3 \%$ didn't know that. $28.3 \%$ said that the virus can be transmitted by shaking hands. The majority $(58.3 \%)$ said that the virus can be transmitted through sharing the sharp equipment, $31.7 \%$ did not know whether it could be transmitted in such manner or not; $33.3 \%$ stated that the symptoms do not appear immediately after infection, while $43.3 \%$ said that the symptoms appear immediately. Also, $58.3 \%$ knew that jaundice and dark urine are some of the symptoms of the disease, $58.3 \%$ knew that the diagnosis is done through testing urine and blood. Regarding complications of the infection: $60 \%$ stated that liver cirrhosis and hepatic cancer are complications of the disease. Most of the respondents (85\%) knew that using gloves and sterile equipment are ways of prevention. Overall about half (51.7\%) of the participants had good knowledge (answered $>65 \%$ of the questions correctly), 26.7 had moderate knowledge (answered 50-65\% of the questions correctly) and 21.7 had poor knowledge (answered $<50 \%$ of the questions correctly).

Table 2. Frequency distribution of students' Knowledge, Attitude, and Practice about hepatitis B infection

\begin{tabular}{|l|l|l|l|}
\hline Variable & Score* & Frequency & Percent \\
\hline Knowledge & Good & 31 & 16.7 \\
\cline { 2 - 4 } & Moderate & 16 & 35 \\
\cline { 2 - 4 } & Poor & 13 & 48.3 \\
\hline Attitude & Good & 10 & 16.7 \\
\cline { 2 - 4 } & Moderate & 21 & 35 \\
\cline { 2 - 4 } & Poor & 29 & 48.3 \\
\hline Practice & Good & 46 & 76.7 \\
\cline { 2 - 4 } & Moderate & 7 & 11.7 \\
\cline { 2 - 4 } & Poor & 7 & 11.7 \\
\hline \multirow{2}{*}{$*$ Good $(>65 \%)$, Moderate (50-65\%), Poor $(<50 \%)$}
\end{tabular}

\subsection{Attitude}

Regarding the students' attitudes (Table 2), half of the students said that they will live with an infected husband, $56.7 \%$ opined they will not travel to a place where the disease is endemic, $46.7 \%$ will live in the same house with an infected person, $48.3 \%$ will not work in the same place with an infected person. On the other hand, $60 \%$ will not marry an infected person, $65 \%$ are willing to help an infected person in case of an accident or emergency, $45 \%$ said that the infected mother can breastfeed her baby, and $75 \%$ feel pity toward the patient with hepatitis B. Overall only $16.7 \%$ of the participants had good attitudes (answered $>65 \%$ of the questions correctly), $35 \%$ had moderate attitudes (answered 50-65\% of the questions correctly) and most of them(48.3\%) had poor attitudes (answered $<50 \%$ of the questions correctly). 


\subsection{Practice}

Regarding the students' practices about hepatitis B infection, $83.3 \%$ strongly agreed not to put hands in medical waste containers, $76.7 \%$ strongly agreed not to throw medical wastes in the opened piles of garbage in the streets, $91.7 \%$ strongly agreed that colored plastic bags should be used to distinguish between medical and general waste, $70 \%$ strongly agreed that the vessels used for medical waste should be cleaned with disinfectant at least once a day and the cleaners should wear thick gloves and eye masks when cleaning them, $68.3 \%$ strongly agreed that the red bags are used for infectious and disease-borne waste, which must be disposed of by burning, $60 \%$ strongly agreed that the yellow bags, used for radioactive waste and to be sent to bodies operating in atomic energy to deal with, $66.7 \%$ strongly agreed to that the black bags are used for general waste, which are disposed of in normal ways and transported by cars belonging to local councils, $88.3 \%$ strongly agreed not to dump medical waste in open vehicles, which increases the risk of injury to workers, patients and visitors, $86.7 \%$ strongly agreed to that waste disposal containers should be covered. Regarding the practice about hepatitis B infection, overall most $(76.7 \%)$ of the participants had good practices (answered $>65 \%$ of the questions correctly), $11.7 \%$ had moderate practices (answered $50-65 \%$ of the questions correctly) and only $11.7 \%$ had poor practices (answered $<50 \%$ of the questions correctly).

\subsection{KAP model: Relationship between study variables}

Table 3 shows the relationship between demographic characteristics and KAP groups. Age and education were not significantly associated with knowledge or practice of HBV infection. A significant difference was found between the marital status and the attitude towards HBV infection $(\mathrm{p}=0.024)$.

Table 3. The relation between demographic variables and knowledge, attitude and practice

\begin{tabular}{|l|l|l|}
\hline KAP & Demographic Variables & p-value \\
\hline Knowledge & Age & 0.763 \\
\cline { 2 - 3 } & Marital status & 0.517 \\
\cline { 2 - 3 } & Education & 0.115 \\
\hline Attitude & Age & 0.055 \\
\cline { 2 - 3 } & Marital status & 0.024 \\
\cline { 2 - 3 } & Education & 0.114 \\
\hline Practice & Age & 0.855 \\
\cline { 2 - 3 } & Marital status & 0.929 \\
\cline { 2 - 3 } & Education & 0.481 \\
\hline
\end{tabular}

\section{Discussion}

This study was carried out to assess the KAP of students in the nursing department at Sabya University College of Jazan University (Kingdom of Saudi Arabia) towards hepatitis B virus infection. Hepatitis B virus Infection is very dangerous as it leads to chronic and often fatal liver diseases such as liver cirrhosis and cancer. Health care workers and students in health professions are at great risk (18) and this risk can be greatly reduced by having adequate knowledge and applying the right practices. The results of this study revealed that the level of knowledge is inadequate among the participants as $23.3 \%$ did not hear about the disease so most probably they guessed the answers to the rest of the questions. On the contrary, ul-Haqet al. in Pakistan reported that $84 \%$ of the participants heard about the disease (19), 20.0\% did not know the causative agent of the disease, $35.0 \%$ did not know that the health workers are at high risk of contracting the disease, $40.0 \%$ did not know the virus can be transmitted through body fluids, $31.7 \%$ did know that the virus can be transmitted through a sharp object. A study in Northwest Ethiopia found that most (97.2\%) of the medical students' respondents knew that HBV can be transmitted by contaminated blood and body fluids while 96.7 knew that it can be transmitted by unsterilized syringes, needles and surgical instruments(18). On the other hand, this lack of knowledge about the disease is consistent with another study done among dental students and interns in Saudi Arabia (16) which concluded that Saudi dental students have a fairly unsatisfactory level of knowledge regarding HBV infection. Another study showed that HBV- and HCV-related $\mathrm{KAP}$ in a sample of Iranian health sciences students was not satisfying (20).

The participants had a negative attitude towards hepatitis $\mathrm{B}$ infected patients, $48.3 \%$ answered $<50 \%$ of the questions related to attitude correctly, this may be related to the lack of knowledge, although there was no direct relationship between the knowledge and attitude. This result is in agreement with another study about Knowledge, attitude, and behavior of hepatitis B virus infection among Chinese dental interns (21). In contrast, a recent study in 
KSA conducted among the healthy population showed that there was a good knowledge of HBV (22). This may be attributed to that the healthy people are not at great risk of infection and the nurses are more exposed to patients' blood or other procedures that may lead to transmission of the disease, making them less willing to deal with hepatitis B infected clients. Despite the lack of knowledge and the negative attitudes of the participants, the result of practice was good, $76.7 \%$ had good practices. This finding is contrary to a similar study performed among dental professions in India which showed that the infection control measures among the health care professionals are moderately poor (23). Our results were in line with the findings in the study conducted by Al-Shamiri and his colleagues (16) which showed that the dental students and interns have poor knowledge but adequate practices. Although the knowledge was poor, the participants' practices were good which may be attributed to the general principles of infection control that are taught to the students in the school.

\section{Conclusions}

The lack of students' knowledge about hepatitis B which was evident from this study indicates that the students are at risk of infection, and this poor knowledge resulted in their negative attitudes toward Hepatitis B virus-infected patients. Health education programs should be promoted to improve the Knowledge, attitude, and practice of the students in the health professions as well as the public about HBV infection. Strengthening of prevention programs should be carried out by the Ministry Of Health. The knowledge and attitude regarding hepatitis B virus infection will improve shortly if continuous efforts are made to increase the awareness about the disease.

\section{Acknowledgments:}

We would like to show our gratitude to Jazan University for providing approval and technical support for the development and implementation of this study.

\section{Conflict of Interest:}

There is no conflict of interest to be declared.

\section{Authors' contributions:}

Conception or design of the work (HAM, MBM); Acquisition of data (NHA, KMIZ); Analysis or interpretation of data (HAM, MBM, IKAG); Drafting and revising the manuscript (All authors); All authors read and approved the final manuscript. All authors are accountable for all aspects of the work.

\section{References:}

1) Afihene M, Duduyemi B, A-Tetteh H-L, Khatib $\mathrm{M}$ et al. Knowledge, attitude and practices concerning Hepatitis B infection, among healthcare workers in Bantama, Ghana: a cross sectional study. Int. J. Community Med. Public Heal. 2015; 2(3), 244-53. https://doi.org/10.18203/2394-6040.ijcmph20150477

2) BJ LAsm et al. Chronic hepatitis B. Hepatol (Baltimore, Md). 2007; 45(2), 507-39. https://doi.org/10.1002/hep.21513 PMid: 17256718

3) Kennedy PTF, Litwin S, Dolman GE, Bertoletti A, Mason WS et al. Immune tolerant chronic hepatitis B: The unrecognized risks. Viruses. 2017; 9 (5), 96. https://doi.org/10.3390/v9050096 PMid: 28468285 PMCid: PMC5454409

4) Chang $\mathrm{MH}$ et al. Hepatitis b virus infection. In: Liver Disease in Children, Fourth Edition (Cambridge University Press). 2011; 176-294.

5) McMahon BJ, Alward WLM, Hall DB, et al. Acute hepatitis B virus infection: Relation of age to the clinical expression of disease and subsequent development of the carrier state. J. Infect. Dis. 1985; 151(4), 599-603. https://doi.org/10.1093/infdis/151.4.599 PMid: 3973412

6) Gambarin-Gelwan M et al. Hepatitis B in pregnancy. Clin. Liver Dis. 2007; 11(4), 945-63. https://doi.org/10.1016/j.cld.2007.08.004 PMid: 17981236

7) Lai CL, Ratziu V, Yuen M-F, Poynard T et al. Viral hepatitis B. Lancet. 2003; 362(9401), 2089-94. https://doi.org/10.1016/S0140-6736(03)15108-2

8) Alter MJ. Epidemiology of hepatitis B in Europe and worldwide. J. Hepatol. 2003; 39, 64-9. https://doi.org/10.1016/S0168-8278(03)00141-7

9) Alqahtani JM, Abu-Eshy SA, Mahfouz AA, El-Mekki AA, Asaad AM et al. Seroprevalence of hepatitis B and $\mathrm{C}$ virus infections among health students and health care workers in the Najran region, southwestern Saudi Arabia: The need for national guidelines for health students. BMC Public Health. 2014; 14(1), 577. https://doi.org/10.1186/1471-2458-14-577 PMid: 24912684 PMCid: PMC4059075 
10) Ageely H, Mahfouz MS, Gaffar A, Elmakki E, Elhassan I, Yasin AO, et al. Prevalence and Risk Factors of Hepatitis B Virus in Jazan Region, Saudi Arabia: Cross-Sectional Health Facility Based Study. Health. 2015; 7(4), 459-65. https://doi.org/10.4236/health.2015.74054

11) Abdullah SM. Prevalence of hepatitis $B$ and $C$ virus infection and their co-relation with hematological and hepatic parameters in subjects undergoing premarital screening in the Jazan Region, Kingdom of Saudi Arabia. Pakistan J Med Sci. 2018; 34(2), 316-21. https://doi.org/10.12669/pjms.342.14278 PMid: 29805400 PMCid: PMC5954371

12) Abdullah SM. Prevalence of hepatitis B and C in donated blood from the Jazan region of Saudi Arabia. MalaysianJ Med Sci. 2013; 20(2), 41-6

13) WHO | Hepatitis C. World Health Organization; Fact sheet No. 164, Updated April (2014).

14) Shepard CW, Simard EP, Finelli L, Fiore AE, Bell BP et al. Hepatitis B virus infection: Epidemiology and vaccination., Epidemiol. Rev. 2006; 28(1), 112-25. https://doi.org/10.1093/epirev/mxj009 PMid: 16754644

15) Abeje G, Azage M. et al. Hepatitis B vaccine knowledge and vaccination status among health care workers of Bahir Dar City Administration, Northwest Ethiopia: A cross sectional study. BMC Infect. Dis. 2015; (15), 30. https://doi.org/10.1186/s12879-015-0756-8 PMid: 25637342 PMCid: PMC4324798

16) Al-Shamiri HM, AlShalawi FE, AlJumah TM, AlHarthi MM, AlAli EM, AlHarthi HM et al. Knowledge, attitude and practice of Hepatitis B virus infection among dental students and interns in Saudi Arabia. J. Clin. Exp. Dent. 2018; 10(1), 54-60.

17) Ali Alhowaish J, Ali Alhowaish M, Hamoud Alanazi Y et al. Knowledge, attitudes and practices toward prevention of hepatitis B virus infection among medical students at Northern Border University, Arar, Kingdom of Saudi Arabia. Electron. Physician.2017; 9(9), 5388-94. https://doi.org/10.19082/5388 PMid: 29038726 PMCid: PMC5633242

18) Abdela A, Woldu B, Haile K, Mathewos B, Deressa T et al. Assessment of knowledge, attitudes and practices toward prevention of hepatitis $\mathrm{B}$ virus infection among students of medicine and health sciences in Northwest Ethiopia. BMC Res. Notes. 2016 9(1), 410. https://doi.org/10.1186/s13104-016-2216-y PMid: 27543117 PMCid: PMC4992214

19) Ul Haq N, Hassali MA, Shafie AA, Saleem F, Farooqui M, Aljadhey H et al. A cross sectional assessment of knowledge, attitude and practice towards Hepatitis B among healthy population of Quetta, Pakistan. BMC Public Health. 2012; 12(1), 692. https://doi.org/10.1186/1471-2458-12-692 PMid: 22917489 PMCid: PMC3490724

20) Karimi-Sari H, Bayatpoor ME, Aftabi Khotbesara M, Ebrahimi MS, Sattari Z, Sattari P, et al. Knowledge, attitude, and practice of Iranian health sciences students regarding hepatitis B and C virus infections: A national survey. Am. J. Infect. Control. 2017; 45(11), 135-41. https://doi.org/10.1016/j.ajic.2017.07.012 PMid: 28893448

21) Li X, Kang H, Wang S, Deng Z, Yang T, Jia Y YY et al. Knowledge, attitude, and behavior of hepatitis B virus infection among Chinese dental interns. Hepat. Mon. 2015; 15(5). https://doi.org/10.5812/hepatmon.15(5)2015.25079

22) Wedhaya MA et al. ASSESSMENT OF KNOWLEDGE, ATTITUDE AND PRACTICE TOWARDS HEPATITIS B AMONG HEALTHY POPULATION IN SAUDI ARABIA, 2017. World J Pharm Res. 126 35. https://doi.org/10.20959/wjpr201711-9634

23) Sudhakara Reddy R, Swapna LA, Ramesh T, Pradeep K et al. Knowledge, attitude and practice on hepatitis B prevention among dental professionals in India. Brazilian J Oral Sci. 2011; 10(4), 241-5. 